\title{
WATER RETENTION AND S INDEX OF AN OXISOL SUBJECTED TO WEED CONTROL METHODS IN A COFFEE CROP
}

\author{
Retenção de água e índice $\mathrm{S}$ de um Latossolo Vermelho-Amarelo submetido a \\ métodos de controle de plantas invasoras na cultura do café
}

\author{
Raphael Henrique da Silva Siqueira ${ }^{1}$, Mozart Martins Ferreira ${ }^{2}$, Elifas Nunes de Alcântara ${ }^{3}$, \\ Bruno Montoani Silva ${ }^{2}$, Raphael Comanducci Silva ${ }^{2}$
}

\begin{abstract}
Weed control in different crops affects the chemical, physical, and biological properties of the soil and consequently its structural quality. The objective of this study was to evaluate, using water retention characteristics and the $S$ index, the physical quality of an Oxisol (Red-Yellow Latosol), subjected to weed control during the cultivation of coffee. The following weed control methods were evaluated: harrowing, brushcutting, residue crushing, manual weeding, post-emergence herbicide application, preemergence herbicide application, and maintenance of soil cover with peanut forage, Brachiaria grass, and spontaneous vegetation (no weed treatment). The following properties were determined for physical characterization of the soil: bulk density, total porosity, macroporosity, microporosity, water retention, and the $\mathrm{S}$ index. The weed control method significantly affected the physical properties and water retention in the subsurface layer of the Oxisol. Soil bulk density, total porosity, macroporosity, and microporosity were significantly correlated with the $\mathrm{S}$ index. According to the $\mathrm{S}$ index, the physical quality of the soil was classified as very good for the various weed control methods investigated.
\end{abstract}

Index terms: Weed management, physical quality of the soil, soil water retention.

\section{RESUMO}

O controle das plantas daninhas nos diferentes cultivos influenciam atributos químicos, físicos e biológicos do solo e consequentemente sua qualidade estrutural. O objetivo deste trabalho foi avaliar, por meio da retenção de água e do índice $\mathrm{S}$, a qualidade física de um Latossolo Vermelho-Amarelo (LVAd) submetido a métodos de controle de plantas invasoras na cultura do café. Foram avaliados os seguintes métodos de controle de plantas invasoras: grade, roçadora, trincha, capina manual, herbicida de pós-emergência, herbicida de pré-emergência, emanutenção da cobertura do solo com amendoim-forrageiro, capim-braquiária e vegetação espontânea (tratamento sem capina). Para a caracterização física do solo foram determinados os seguintes atributos do solo: densidade do solo, porosidade total, macroporosidade, microporosidade, retenção de água e o índice S. Os métodos de controle das plantas invasoras afetaram significativamente os atributos físicos e a retenção de água das camadas superficial e subsuperficial do Latossolo Vermelho-Amarelo. Densidade do solo, porosidade total, macroporosidade e microporosidade correlacionaram-se significativamente com o índice $\mathrm{S}$. De acordo com o índice $\mathrm{S}$, a qualidade física do solo foi classificada como muito boa para os diversos métodos de controle empregados.

Termos para indexação: Manejo de plantas daninhas, qualidade física do solo, retenção de água.

\section{INTRODUCTION}

Previous studies have shown that the use of different management and weed control systems for coffee cultivation influences the physical, chemical, and biological properties of the soil (Alcântara et al., 2007; Pais et al., 2011; Araujo-Junior et al., 2011; Melloni et al., 2013). In general, such systems should contribute to the improvement or maintenance of the physical quality of the soil and the environment as a whole, and should also ensure satisfactory long-term crop yields (Costa et al., 2003). Alcântara and Ferreira (2000) showed that different weed control methods in coffee plantations influenced the physical quality of the soil, most significantly in the $0-15 \mathrm{~cm}$ layer.

According to Dexter (2004), the physical quality of the soil manifests in various ways and the degradation of the soil structure is a common cause of poor physical quality. Soil structure refers to the arrangement of the particles that make up the soil, forming a porous system. According to Ferreira (2010), soil structure has a dynamic nature, and any alteration in the pore space will lead to an alteration in the behavior of the processes occurring within the soil.

${ }^{1}$ Universidade Federal de Lavras/UFLA - Departamento de Ciência do Solo/DCS - Cx. P. 3020 - $37200-000$ - Lavras - MG - Brasil raphael_manejosolo@hotmail.com

¿Universidade Federal de Lavras/UFLA - Departamento de Ciência do Solo/DCS - Lavras - MG - Brasil

${ }^{3}$ Empresa de Pesquisa Agropecuária de Minas Gerais/EPAMIG - Lavras - MG - Brasil

Received in april 08, 2014 and approved in august 20, 2014 
The impacts of land use and management have been quantified according to the physical attributes that determine the structural stability of the soil. The attributes most commonly used for soil physical characterization are aggregate stability, porosity, and soil bulk density (Bd) (Aratani et al., 2009).

The use of the $\mathrm{S}$ index as a parameter for evaluating the physical quality of the soil was proposed by Dexter (2004). The value of the $\mathrm{S}$ index is dependent on the characteristic water retention curve (WRC) and represents the slope at its inflection point. In the study by Dexter (2004), an S index of 0.035 was reported as the borderline between soils with good and poor structural quality.

Andrade and Stone (2009) evaluated the S index as an indicator of the physical quality of soils of the Brazilian Cerrado, allowing meaningful comparison with the present study. According to these authors, the $\mathrm{S}$ index was an appropriate indicator of the physical quality of the soil in the Cerrado, and an S index of 0.045 reflected the distinction between good soil structure and soil structure at risk of degradation. The usefulness of the $\mathrm{S}$ index for assessing the physical quality of the soil has also been demonstrated in a number of other studies (Tormena et al., 2008; Streck et al., 2008; Beutler et al., 2008; Pereira et al., 2010; Cavalieri et al., 2011; Calonego; Rosolem, 2011; Mota et al., 2012; Silva et al., 2012).

The hypothesis of present study is that weed control methods that improve the physical quality of the soil will result in higher values of the $\mathrm{S}$ index. Given the considerations above, this work seeks to evaluate the water retention characteristics and the $\mathrm{S}$ index in an Oxisol cultivated with coffee and subjected to different weed control methods.

\section{MATERIAL AND METHODS}

The present study was conducted on the Dr. Silvio Menicucci experimental farm belonging to the Empresa de Pesquisa Agropecuaria de Minas Gerais (EPAMIG) $\left(45^{\circ} 06^{\prime} 43.8^{\prime \prime} \mathrm{W}, 21^{\circ} 21^{\prime} 12^{\prime \prime} \mathrm{S}\right)$, located in Lavras, Minas
Gerais (MG), Brazil. The average annual rainfall at the study site is $1511 \mathrm{~mm}$ and the average relative humidity is $76.2 \%$ (Brasil, 1992). According to the Köppen climate classification, the region has a Cwa climate, characterized as subtropical with a dry winter and prevailing summer rainfall. The soil at the site is an Oxisol, classified as a dystrophic Red-Yellow Latosol (LVAd) with a clayey texture. The chemical and physical characterization of the soil at the study site is shown in table 1 .

The installation of the coffee crop took place in January 2005. The cultivar planted was IAC Catuaí 99, with a spacing of $0.8 \mathrm{~m}$ between plants and $3.5 \mathrm{~m}$ between rows. The various methods of weed control (Table 2) were applied in strips to facilitate field operations. The data for this study were collected in January 2012, seven years after the beginning of the experiment.

The details of the weed control methods are as follows: Peanut forage (PF) planted on installation at a density of $150 \mathrm{~kg} \mathrm{ha}^{-1}$; Brushcutting (BC) with a Kamaq KDD ECO 230 Cruiser brushcutter with an approximate mass of $560 \mathrm{~kg}$ (average of five operations); Harrowing (HR) with 16 disks arranged in a $\mathrm{V}$ and an approximate mass of $262 \mathrm{~kg}$ (average of three operations); Residue crushing (RC) with an RB Tritton 1300 with six rows of hammers and an approximate mass of $570 \mathrm{~kg}$ (average of five operations); Post-emergence herbicide (PstH), glyphosate at $3 \mathrm{~L} \mathrm{ha}^{-1}$ in $300 \mathrm{~L}$ of water (an average of three applications); Pre-emergence herbicide (PreH), oxyfluorfen at a dose of $3 \mathrm{~L} \mathrm{ha}^{-1}$ in $300 \mathrm{~L}$ of water (an average of two applications); Manual weeding (MW) (average of five operations); No weeding (NW); and Brachiaria grass (BR) planted on installation at a density of $150 \mathrm{~kg} \mathrm{ha}^{-1}$.

In each strip of about $144 \mathrm{~m}$ in length, three 48 $\mathrm{m}$ parcels were randomized, each containing 60 holes for coffee plants. Each control method was applied to two adjacent strips, so that one served as a border for the surrounding treatments. The experimental had a $9 \times 2$ factorial, randomized block, split-plot design. The factors were the nine weed control methods and two soil depths, with three replications.

Table 1 - Physical and chemical characterization of the 0-15 and 15-30 cm layers of the Oxisol at the study site.

\begin{tabular}{|c|c|c|c|c|c|c|c|c|c|c|c|c|}
\hline \multirow{2}{*}{$\begin{array}{c}\text { Layer } \\
(\mathrm{cm})\end{array}$} & Sand & Silt & Clay & \multirow[t]{2}{*}{$\mathrm{pH}$} & $\mathrm{K}$ & $\mathrm{P}$ & $\mathrm{Ca}$ & $\mathrm{Mg}$ & $\mathrm{Al}$ & SB & $\mathrm{T}$ & \multirow{2}{*}{$\begin{array}{c}\mathrm{V} \\
(\%)\end{array}$} \\
\hline & \multicolumn{3}{|c|}{-------g kg ${ }^{-1}-------$} & & \multicolumn{3}{|c|}{$--\mathrm{mg} \mathrm{dm}{ }^{-3}--$} & \multicolumn{4}{|c|}{ - } & \\
\hline $0-15$ & 130 & 330 & 540 & 5.9 & 176.45 & 0.65 & 1.31 & 0.88 & 0.15 & 2.64 & 2.79 & 43.53 \\
\hline $15-30$ & 110 & 360 & 530 & 5.8 & 120.99 & 0.56 & 0.64 & 0.47 & 0.28 & 1.42 & 1.70 & 25.08 \\
\hline
\end{tabular}

Ciênc. Agrotec., Lavras, v.38, n.5, p.471-479, set./out., 2014 
At the time of the installation of the coffee crop, the equivalent of $3 \mathrm{tha}^{-1}$ of agricultural gypsum and $500 \mathrm{~kg} \mathrm{ha}^{-1}$ of 20-5-20 NPK were applied in the planting furrows, plus $300 \mathrm{~g}$ per hole of simple superphosphate. The weed control operations were initiated when $90 \%$ of the soil between rows was covered by weeds (Table 3 ) and/or the plants were approximately $0.45 \mathrm{~m}$ tall.

Undisturbed samples were used for the determination of the physical properties of the soil and WRCs of the nine treatments. Samples were collected with Uhland samplers, with average ring dimensions of $4.90 \mathrm{~cm}$ in diameter and $2.65 \mathrm{~cm}$ in height. The volumetric ring method (Blake; Hartge, 1986) was used to determine the soil $\mathrm{Bd}$ and the pycnometer method (Flint, Flint, 2002) was used to determine particle density (Pd). The total porosity (TP) was calculated using the formula $\mathrm{TP}=(1-\mathrm{Bd} / \mathrm{Pd}) \times 100$. The microporosity (Micro) was determined as equivalent to the water content of the sample at a tension of $6 \mathrm{kPa}$ (Oliveira, 1968) in a suction unit composed of Buchner funnels, which promoted the drainage of the sample at different suction heights, emptying the soil pores of a target diameter. The macroporosity (Macro) was calculated as the difference between TP and Micro. For the water retention evaluation, undisturbed soil samples were saturated and then subjected to tensions corresponding to $-2,-4,-6$, and $-10 \mathrm{kPa}$, using the suction unit and

Table 2 - Weed control methods in Oxisol cultivated with coffee in Lavras, MG.

\begin{tabular}{cc}
\hline Control Method & Identification \\
\hline Peanut forage (Arachis pintoi L.) & PF \\
Harrowing & HR \\
Brushcutting & BC \\
Residue Crushing & RC \\
Post-emergence Herbicide & PstH \\
Pre-emergence Herbicide & PreH \\
Manual Weeding & MW \\
No Weeding & NW \\
Brachiaria grass (Brachiaria decumbens) & BR \\
\hline
\end{tabular}

Table 3 - Principal weed species present in the experimental area, classified according to Lorenzi (2006).

\begin{tabular}{cc}
\hline Scientific Name & Popular Name \\
\hline Brachiaria decumbens Stapff. & Surinam grass \\
Bidens pilosa L. & Spanish needle \\
Portulaca oleracea L. & Pigweed \\
Vernonia spp. & Ironweed \\
Baccharis dracunculifolia DC. & Broom \\
Conyza canadensis (L.) Cronquist. & Horseweed \\
Sida rhombifolia L. & Arrowleaf sida \\
Pennisetum purpureum Schum. & Napier grass \\
Digitaria horizontalis Willd. & Crabgrass \\
Amaranthus hibridus L. & Smooth amaranth \\
Spermacoce latifólia Aubl. & Oval-leaf false buttonweed \\
Sida cordifolia L. & Flannel weed \\
Digitaria insularis (L.) Fedde. & Sourgrass \\
\hline
\end{tabular}


to tensions of $-33,-100,-500$, and $-1500 \mathrm{kPa}$, using the Richards extractor (Klute, 1986). The WRCs were obtained by nonlinear fitting of the gravimetric water content values $(\mathrm{U})$ as a function of soil water tension $(\mathrm{kPa})$ to the model proposed by Van Genuchten (1980) with the Mualem constraint $[\mathrm{m}=1-(1 / \mathrm{n})]$ using RTEC software (Van Genuchten et al., 2009).

The $\mathrm{S}$ index values were calculated on a weight basis according to Dexter (2004) using the following equation:

$$
S=-n\left(U_{s a t}-U_{r e s}\right) \cdot\left[1+\frac{1}{m}\right]^{-(1+m)}
$$

Where:

$\mathrm{S}=$ the slope of the WRC at its inflection point;

$\mathrm{U}_{\text {sat }}=$ saturated water content $\left(\mathrm{kg} \mathrm{kg}^{-1}\right)$;
$\mathrm{U}_{\text {res }}=$ residual water content $\left(\mathrm{kg} \mathrm{kg}^{-1}\right)$;

and $\mathrm{m}$ and $\mathrm{n}=$ equation empirical parameters.

The results of physical characterization and water retention were subjected to analysis of variance and averages were compared by the Scott-Knott test at $5 \%$ probability. SISVAR statistical software (Ferreira, 2011) was used for both procedures. Correlation analysis between variables was carried out using SigmaPlot software (SigmaPlot, 2011).

\section{RESULTS AND DISCUSSION}

In the present study, significant differences among the different weed control methods were only found among the physical properties of the soil in the $15-30 \mathrm{~cm}$ layer (Table 4). However, in the study by Alcântara and Ferreira (2000), weed control methods did not affect the physical quality of the soil in this deeper layer.

Table 4 - Soil bulk density (Bd), total porosity (TP), macroporosity (Macro), and microporosity (Micro) of an Oxisol subjected to weed control methods in the cultivation of coffee.

\begin{tabular}{|c|c|c|c|c|}
\hline Control Methods & $\mathrm{Bd}$ & $\mathrm{TP}$ & Macro & Micro \\
\hline & $\mathrm{mg} \mathrm{m}^{-3}$ & & $\mathrm{n}^{3} \mathrm{~cm}^{-3-}$ & \\
\hline \multicolumn{5}{|c|}{ Layer $0-15 \mathrm{~cm}$} \\
\hline $\mathrm{PF}$ & $1.11 \mathrm{a}$ & $0.58 \mathrm{a}$ & $0.21 \mathrm{a}$ & $0.37 \mathrm{a}$ \\
\hline HR & $1.13 \mathrm{a}$ & $0.58 \mathrm{a}$ & $0.20 \mathrm{a}$ & $0.38 \mathrm{a}$ \\
\hline $\mathrm{BC}$ & $1.14 \mathrm{a}$ & $0.57 \mathrm{a}$ & $0.20 \mathrm{a}$ & $0.37 \mathrm{a}$ \\
\hline $\mathrm{RC}$ & $1.12 \mathrm{a}$ & $0.58 \mathrm{a}$ & $0.21 \mathrm{a}$ & $0.37 \mathrm{a}$ \\
\hline PstH & $1.08 \mathrm{a}$ & $0.60 \mathrm{a}$ & $0.24 \mathrm{a}$ & $0.36 \mathrm{a}$ \\
\hline PreH & $1.11 \mathrm{a}$ & $0.58 \mathrm{a}$ & $0.19 \mathrm{a}$ & $0.39 \mathrm{a}$ \\
\hline MW & $1.12 \mathrm{a}$ & $0.57 \mathrm{a}$ & $0.19 \mathrm{a}$ & $0.38 \mathrm{a}$ \\
\hline NW & $1.16 \mathrm{a}$ & $0.56 \mathrm{a}$ & $0.16 \mathrm{a}$ & $0.40 \mathrm{a}$ \\
\hline $\mathrm{BR}$ & $1.15 \mathrm{a}$ & $0.56 \mathrm{a}$ & $0.18 \mathrm{a}$ & $0.38 \mathrm{a}$ \\
\hline \multicolumn{5}{|c|}{ Layer $15-30 \mathrm{~cm}$} \\
\hline $\mathrm{PF}$ & $1.14 b$ & $0.57 b$ & $0.20 \mathrm{~b}$ & $0.37 \mathrm{~b}$ \\
\hline HR & $1.13 \mathrm{~b}$ & $0.58 \mathrm{~b}$ & $0.20 \mathrm{~b}$ & $0.38 b$ \\
\hline $\mathrm{BC}$ & $1.07 \mathrm{c}$ & $0.60 \mathrm{~b}$ & $0.23 b$ & $0.37 \mathrm{~b}$ \\
\hline $\mathrm{RC}$ & $1.01 \mathrm{~d}$ & $0.63 \mathrm{a}$ & $0.27 \mathrm{a}$ & $0.36 \mathrm{~b}$ \\
\hline PstH & $0.94 d$ & $0.64 \mathrm{a}$ & $0.30 \mathrm{a}$ & $0.34 \mathrm{~b}$ \\
\hline PreH & $1.05 \mathrm{c}$ & $0.60 \mathrm{~b}$ & $0.24 b$ & $0.36 \mathrm{~b}$ \\
\hline MW & $1.05 \mathrm{c}$ & $0.60 \mathrm{~b}$ & $0.25 b$ & $0.35 b$ \\
\hline NW & $1.05 \mathrm{c}$ & $0.60 \mathrm{~b}$ & $0.25 b$ & $0.35 b$ \\
\hline $\mathrm{BR}$ & $1.30 \mathrm{a}$ & $0.51 \mathrm{c}$ & $0.09 \mathrm{c}$ & $0.42 \mathrm{a}$ \\
\hline
\end{tabular}

Averages followed by the same letter in columns within each layer do not differ by the Scott-Knott test at 5\% probability. 
In the specific case of the BR plot, there was a higher Bd, lower TP and Macro, and a higher number of micropores in the 15-30 cm layer compared with the 0-15 $\mathrm{cm}$ layer. Conversely, lower Bd and higher TP and Macro were observed where weed control was performed with PstH or RC. A study by Pragana et al. (2012), to assess differences in the soil physical attributes of no tillage and conventional tillage systems in a typical dystrophic Yellow Latosol, found higher absolute Bd values in soils with less soil turnover (no tillage) compared with soils subjected to conventional tillage.

Carmo et al. (2011) evaluated the effect of different coffee cultivation systems on soil physical properties and observed lower soil $\mathrm{Bd}$ in native forest and coffee plantations without mechanization, while slightly higher
Bd was observed in high stand density farming and mechanized farming, although the differences were not significant. Higher Micro was also observed by Pereira et al. (2010), also using a grass, Pearl millet (Pennisetum americanum (L.) Leeke), in an experiment to evaluate the physical quality of a soil cultivated with maize subjected to cover crops, pre-harvest.

Similar to the physical attributes, almost all the differences in water retention among the different weed control methods were observed in the $15-30 \mathrm{~cm}$ layer (Table 5).

As shown in figures 1 and 2, the differences in WRCs among different weed control methods were larger in the $15-30 \mathrm{~cm}$ layer (Figure 2) than in the $0-15 \mathrm{~cm}$ layer (Figure 1).

Table 5 - Water retention at various applied tensions in an Oxisol subjected to weed control methods in the cultivation of coffee.

\begin{tabular}{|c|c|c|c|c|c|c|c|c|c|}
\hline \multirow{2}{*}{$\begin{array}{l}\text { Control } \\
\text { Methods }\end{array}$} & \multicolumn{9}{|c|}{ Tension $(-\mathrm{kPa})$} \\
\hline & 0 & 2 & 4 & 6 & 10 & 33 & 100 & 500 & 1500 \\
\hline & \multicolumn{9}{|c|}{---------kg kg ${ }^{-1}$-------- } \\
\hline & \multicolumn{9}{|c|}{ Layer $0-15 \mathrm{~cm}$} \\
\hline $\mathrm{PF}$ & $0.54 \mathrm{a}$ & $0.39 \mathrm{a}$ & $0.35 \mathrm{a}$ & $0.34 \mathrm{a}$ & $0.32 b$ & $0.22 b$ & $0.21 \mathrm{a}$ & $0.19 \mathrm{a}$ & $0.18 \mathrm{a}$ \\
\hline HR & $0.53 \mathrm{a}$ & $0.38 \mathrm{a}$ & $0.35 \mathrm{a}$ & $0.33 \mathrm{a}$ & $0.32 b$ & $0.22 b$ & $0.21 \mathrm{a}$ & $0.19 \mathrm{a}$ & $0.18 \mathrm{a}$ \\
\hline $\mathrm{BC}$ & $0.52 \mathrm{a}$ & $0.39 \mathrm{a}$ & $0.35 \mathrm{a}$ & $0.33 \mathrm{a}$ & $0.32 b$ & $0.22 b$ & $0.21 \mathrm{a}$ & $0.19 \mathrm{a}$ & $0,18 \mathrm{a}$ \\
\hline $\mathrm{RC}$ & $0.54 \mathrm{a}$ & $0.40 \mathrm{a}$ & $0.36 \mathrm{a}$ & $0.34 \mathrm{a}$ & $0.33 \mathrm{a}$ & $0.22 b$ & $0.21 \mathrm{a}$ & $0.19 \mathrm{a}$ & $0.18 \mathrm{a}$ \\
\hline PstH & $0.56 \mathrm{a}$ & $0.40 \mathrm{a}$ & $0.36 \mathrm{a}$ & $0.34 \mathrm{a}$ & $0.32 b$ & $0.22 b$ & $0.21 \mathrm{a}$ & $0.19 \mathrm{a}$ & $0.17 \mathrm{a}$ \\
\hline PreH & $0.49 \mathrm{a}$ & $0.42 \mathrm{a}$ & $0.37 \mathrm{a}$ & $0.35 \mathrm{a}$ & $0.34 \mathrm{a}$ & $0.24 \mathrm{a}$ & $0.22 \mathrm{a}$ & $0.20 \mathrm{a}$ & $0.19 \mathrm{a}$ \\
\hline MW & $0.51 \mathrm{a}$ & $0.40 \mathrm{a}$ & $0.36 \mathrm{a}$ & $0.34 \mathrm{a}$ & $0.33 \mathrm{a}$ & $0.23 \mathrm{a}$ & $0.22 \mathrm{a}$ & $0.20 \mathrm{a}$ & $0.19 \mathrm{a}$ \\
\hline NW & $0.47 \mathrm{a}$ & $0.39 a$ & $0.36 \mathrm{a}$ & $0.35 \mathrm{a}$ & $0.33 \mathrm{a}$ & $0.24 \mathrm{a}$ & $0.22 \mathrm{a}$ & $0.20 \mathrm{a}$ & $0.19 \mathrm{a}$ \\
\hline \multirow[t]{2}{*}{$\mathrm{BR}$} & $0.49 \mathrm{a}$ & $0.40 \mathrm{a}$ & $0.36 \mathrm{a}$ & $0.34 \mathrm{a}$ & $0.33 \mathrm{a}$ & $0.23 \mathrm{a}$ & $0.22 \mathrm{a}$ & $0.20 \mathrm{a}$ & $0.18 \mathrm{a}$ \\
\hline & \multicolumn{9}{|c|}{ Layer $15-30 \mathrm{~cm}$} \\
\hline $\mathrm{PF}$ & $0.52 \mathrm{c}$ & $0.38 b$ & $0.34 \mathrm{c}$ & $0.33 \mathrm{c}$ & $0.31 \mathrm{~b}$ & $0.22 \mathrm{a}$ & $0.21 \mathrm{a}$ & $0.19 \mathrm{a}$ & $0.18 \mathrm{a}$ \\
\hline HR & $0.51 \mathrm{c}$ & $0.38 \mathrm{~b}$ & $0.35 \mathrm{c}$ & $0.33 \mathrm{c}$ & $0.32 \mathrm{~b}$ & $0.23 \mathrm{a}$ & $0.21 \mathrm{a}$ & $0.19 \mathrm{a}$ & $0.18 \mathrm{a}$ \\
\hline $\mathrm{BC}$ & $0.56 \mathrm{~b}$ & $0.42 \mathrm{a}$ & $0.37 \mathrm{~b}$ & $0.35 b$ & $0.33 \mathrm{a}$ & $0.22 \mathrm{a}$ & $0.20 \mathrm{a}$ & $0.18 \mathrm{a}$ & $0.17 \mathrm{a}$ \\
\hline $\mathrm{RC}$ & $0.62 b$ & $0.44 \mathrm{a}$ & $0.38 \mathrm{~b}$ & $0.35 b$ & $0.34 \mathrm{a}$ & $0.22 \mathrm{a}$ & $0.21 \mathrm{a}$ & $0.19 \mathrm{a}$ & $0.17 \mathrm{a}$ \\
\hline PstH & $0.70 \mathrm{a}$ & $0.46 \mathrm{a}$ & $0.39 \mathrm{a}$ & $0.37 \mathrm{a}$ & $0.35 \mathrm{a}$ & $0.23 \mathrm{a}$ & $0.20 \mathrm{a}$ & $0.18 \mathrm{a}$ & $0.17 \mathrm{a}$ \\
\hline PreH & $0.61 \mathrm{~b}$ & $0.40 \mathrm{~b}$ & $0.36 \mathrm{~b}$ & $0.35 b$ & $0.33 \mathrm{a}$ & $0.22 \mathrm{a}$ & $0.21 \mathrm{a}$ & $0.19 \mathrm{a}$ & $0.18 \mathrm{a}$ \\
\hline MW & $0.58 \mathrm{~b}$ & $0.41 \mathrm{a}$ & $0.37 \mathrm{~b}$ & $0.34 \mathrm{~b}$ & $0.33 \mathrm{a}$ & $0.23 \mathrm{a}$ & $0.21 \mathrm{a}$ & $0.20 \mathrm{a}$ & $0.19 \mathrm{a}$ \\
\hline NW & $0.55 \mathrm{~b}$ & $0.40 \mathrm{~b}$ & $0.36 \mathrm{~b}$ & $0.35 b$ & $0.33 \mathrm{a}$ & $0.23 \mathrm{a}$ & $0.22 \mathrm{a}$ & $0.20 \mathrm{a}$ & $0.19 \mathrm{a}$ \\
\hline BR & $0.39 \mathrm{~d}$ & $0.35 b$ & $0.33 \mathrm{c}$ & $0.32 \mathrm{c}$ & $0.32 \mathrm{~b}$ & $0.23 \mathrm{a}$ & $0.22 \mathrm{a}$ & $0.20 \mathrm{a}$ & $0.19 \mathrm{a}$ \\
\hline
\end{tabular}

Averages followed by the same letter in columns within each layer do not differ by the Scott-Knott test at 5\% probability. 


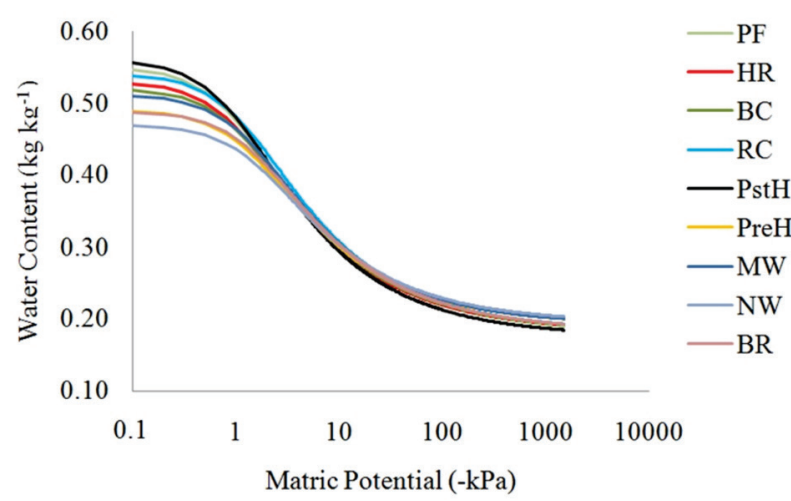

Figure 1 - Water retention curves in the $0-15 \mathrm{~cm}$ layer of an Oxisol subjected to weed control methods in the cultivation of coffee.

As shown in figure 2, among the weed control methods, the strip controlled with BR stands out, having a WRC similar to that for the compacted soil.

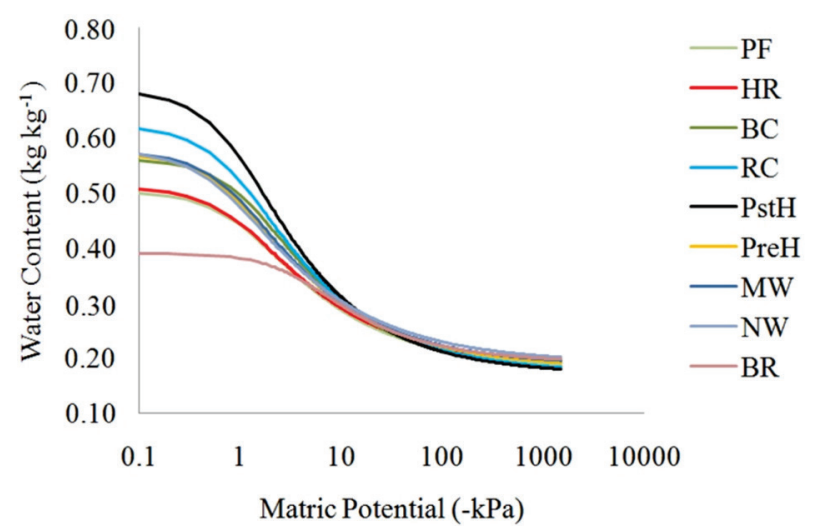

Figure 2 - Water retention curves the $15-30 \mathrm{~cm}$ layer of an Oxisol subjected to weed control methods in the cultivation of coffee.

With a higher Bd and lower TP (Table 4), and thus lower water content at saturation $(0 \mathrm{kPa})$ (Table 5), the WRC for the BR strip is positioned below the others, until the tension reaches about $-6 \mathrm{kPa}$. In soils with higher $\mathrm{Bd}$ there is a reduction in porosity, and in particular, larger diameter pores are suppressed. These larger pores are responsible for water retention at low tensions. Therefore, the higher Bd explains the lower water retention in the strip managed using BR in this experiment. Conversely, the WRCs for strips controlled with PstH or RC showed higher water retention. The results of Araujo-Junior et al. (2011), evaluating the effects of weed control methods on soil porosity and water retention, differed from the results of the present study. Those authors did not observe large differences in water content in the deeper soil layers, but observed large differences in the surface layer. It is important to note that Araujo-Junior et al. (2011) studied the soil with a higher degree of weathering, BR and PF treatments were not included, and the duration of the study was longer.

In the $0-15 \mathrm{~cm}$ layer, the $\mathrm{S}$ index did not differ significantly among weed control methods. Significant differences in the $\mathrm{S}$ index were only observed in the 15-30 cm layer. These results support the results for the physical attributes and water retention discussed above (Table 5).

For Cerrado soils, Andrade and Stone (2009) defined an $\mathrm{S}$ index of 0.045 as the value for separating soils with favorable physical conditions from those with unfavorable conditions. Therefore, the values of the $\mathrm{S}$ index obtained in the present study suggest that the weed control methods have maintained the soil with good structural quality (Table 6).

Silva et al. (2008) also observed higher S index values in the soil maintained without tillage, as is the case in weed control with PstH, which indicates a better soil pore configuration and less physical restriction for the plant roots by aeration, mechanical restriction, or water retention.

Beutler et al. (2008) found that $\mathrm{S}$ index values of 0.056-0.062 limited the development of soybean and corn. Freddi et al. (2009) found positive correlations between maize hybrid productivity and $\mathrm{S}$ index values of $\leq 0.035$, which was established as a limit for the unstructured soil. Higher values were associated with marked declines in corn yield.

Soil Bd, TP, Macro, and Micro are indices traditionally used to assess the physical quality of the soil and to qualify the structural conditions underlying different soil quality. Bd and Micro were negatively correlated with the $\mathrm{S}$ index, while TP and Macro were positively correlated with the $\mathrm{S}$ index (Table 7). This shows that the $\mathrm{S}$ index is sensitive to structural changes in the soil, and varies with the porous soil rearrangement triggered by different management methods.

The correlations shown in table 7 support the use the $\mathrm{S}$ index to assess the physical quality of the soil, as reported by Dexter (2004), Andrade and Stone (2009), Silva et al. (2012), and Emami, Neyshabouri and Shorafa (2012). 
Table 6 - S Index in Oxisol subjected to different weed control methods in the cultivation of coffee.

\begin{tabular}{ccc}
\hline Weed Control Methods & S Index \\
\hline Peanut forage (Arachis pintoi L.) & $0-15 \mathrm{~cm}$ & $15-30 \mathrm{~cm}$ \\
Harrowing & $0.083 \mathrm{aA}$ & $0.077 \mathrm{aB}$ \\
Brushcutting & $0.080 \mathrm{aA}$ & $0.077 \mathrm{aB}$ \\
Residue Crushing & $0.077 \mathrm{aA}$ & $0.097 \mathrm{aA}$ \\
Post-emergence Herbicide & $0.083 \mathrm{aA}$ & $0.110 \mathrm{aA}$ \\
Pre-emergence Herbicide & $0.093 \mathrm{bA}$ & $0.130 \mathrm{aA}$ \\
Manual Weeding & $0.077 \mathrm{aA}$ & $0.100 \mathrm{aA}$ \\
No Weeding & $0.080 \mathrm{aA}$ & $0.097 \mathrm{aA}$ \\
Brachiaria grass (Brachiaria decumbens) & $0.070 \mathrm{aA}$ & $0.080 \mathrm{aB}$ \\
\hline
\end{tabular}

Averages followed by the same letters, lowercase letters in the rows and uppercase letters in the columns, do not differ by the Scott-Knott test at $5 \%$ probability.

Table 7 - Correlations between the $\mathrm{S}$ index and physical attributes of two layers of an Oxisol subjected to weed control methods in the cultivation of coffee.

\begin{tabular}{ccc}
\hline & $0-15 \mathrm{~cm}$ & $15-30 \mathrm{~cm}$ \\
\hline Bd & $-0.90^{* *}$ & $-0.89^{* *}$ \\
TP & $0.91^{* *}$ & $0.86^{* *}$ \\
Macro & $0.91^{* *}$ & $0.88^{* *}$ \\
Micro & $-0.81^{* *}$ & $-0.85^{* *}$ \\
\hline
\end{tabular}

** P value significant at $1 \%$ by the correlation test.

\section{CONCLUSIONS}

The weed control methods used in a coffee crop significantly affected the physical properties and water retention of the subsurface layer $(15-30 \mathrm{~cm})$ of the Oxisol.

Soil Bd, TP, Macro, and Micro were significantly correlated with the $\mathrm{S}$ index.

According to the $\mathrm{S}$ index, the physical quality of the soil was classified as good for the various control methods employed in the present study, with all the values $>0.045$.

\section{REFERENCES}

ALCANTARA, E. N.; NOBREGA, J. C. A.; FERREIRA, M. M. Métodos de controle de plantas invasoras na cultura do cafeeiro (Coffea arabica L.) e componentes da acidez do solo. Revista

Brasileira de Ciência do Solo. 31(6):1525-1533, 2007.
ALCÂNTARA, E.N.; FERREIRA, M.M. Efeitos de métodos de controle de plantas daninhas na cultura do cafeeiro (Coffea arábica L.) sobre a qualidade física do solo. Revista Brasileira de Ciências do Solo. 24:711$721,2000$.

ANDRADE, R. S.; STONE, L. F. Índice S como indicador da qualidade física de solos do cerrado brasileiro. Revista Brasileira de Engenharia Agrícola e Ambiental.13(4):382-388, 2009.

ARATANI, R. G. et al. Qualidade física de um latossolo vermelho acriférrico sob diferentes sistemas de uso e manejo. Revista Brasileira de Ciência do Solo. 33(3):677-687, 2009.

ARAUJO-JUNIOR, C. F. et al. Alterações nos atributos químicos de um latossolo pelo manejo de plantas invasoras em cafeeiros. Revista Brasileira de Ciência do Solo. 35(6):2207-2217, 2011. 
BEUTLER, A. N. et al. Densidade do solo relativa e parâmetro "S" como indicadores da qualidade física para culturas anuais. Revista de Biologia e Ciências da Terra. 8(2):27-36, 2008.

BLAKE, G. R.; HARTGE, K. H. Bulk density. In: KLUTE, A. (Ed.). Methods of soil analysis. Part 1. Physical and mineralogical methods. Madison: ASA/ SSSA, 1986. p.363-375.

BRASIL. Ministério da Agricultura. Departamento Nacional de Meteorologia. Normas climatológicas 1961-1990. Brasília, DF, 1992. 84 p.

CALONEGO, J. C; ROSOLEM, C. A. Soil water retention and $\mathrm{S}$ index after crop rotation and chiseling. Revista Brasileira de Ciência do Solo. 35(6):1927-1937, 2011.

CARMO, D. L. et al. M. Propriedades físicas de um latossolo vermelho-amarelo cultivado com cafeeiro em três sistemas de manejo no sul de minas gerais. Revista Brasileira de Ciência do Solo. 35(3):991-998, 2011.

CAVALIERI, K. M. V. et al. Qualidade física de três solos sob colheita mecanizada de cana-de-açúcar. Revista Brasileira de Ciência do Solo. 35(5):1541-1550, 2011.

COSTA, F. S. et al. Propriedades físicas de um Latossolo bruno afetadas pelos sistemas plantio direto e preparo convencional. Revista Brasileira de Ciência do Solo. 27(3):527-535, 2003.

DEXTER, A. R. Soil physical quality. Part 1. Theory, effects of soil texture, density, and organic matter, and effects on root growth. Geoderma. 120(3-4):201-214, 2004.

EMAMI, H.; NEYSHABOURI, M. R.; SHORAFA, M. Relationships between some soil quality indicators in different agricultural soils from Varamin, Iran. Journal of Agricultural Science and Technology. 14(4):951959, 2012.

FERREIRA, M. M. Caracterização física do solo. In: JONG van LIER, Q. Física do solo. $1^{\mathrm{a}}$ ed. Sociedade Brasileira de Ciência do Solo, Viçosa, 2010. p.1-27.

FERREIRA, D. F. Sisvar: a computer statistical analysis system. Ciência e Agrotecnologia. 35(6):1039-1042, 2011.
FLINT, A.L.; FLINT, L.E. Particle density. In: DANE, J. H.; TOPP, G. C. (Ed). Methods of soil analysis: part 4-physical methods. Madison: American Society of America, 2002. p.229-240.

FREDDI, O. S. et al. Compactação do solo e produção de cultivares de milho em Latossolo Vermelho. I- Características de planta, solo e índice S. Revista Brasileira de Ciência do Solo. 33(4):793803, 2009.

KLUTE, A. Water retention: laboratory methods. In: Klute, A. (ed.). Methods of soil analysis. Madison: American Society of Agronomy, 1986. p.563-596.

LORENZI, H. Manual de identificação e controle de plantas daninhas: plantio direto e convencional. 6.ed. Nova Odessa: Plantarum, 2006. 672p.

MELLONI, R. et al. Métodos de controle de plantas daninhas e seus impactos na qualidade microbiana de solo sob cafeeiro. Revista Brasileira de Ciência do Solo. 37(1):66-75, 2013.

MOTA, F. O. B. et al. Physical quality of an oxisol under different uses. Revista Brasileira de Ciência do Solo. 36(6):1828-1835, 2012.

OLIVEIRA, L. B. Determinação da macro e microporosidade pela "mesa de tensão" em amostras de solo com estrutura indeformada. Pesquisa Agropecuária Brasileira. 3(1):197-200, 1968.

PAIS, P. S. M. et al. Compactação cuasada pelo manejo de plantas invasoras em Latossolo Vermelho-Amarelo cultivado com cafeeiros. Revista Brasileira de Ciência do Solo. 35(6):1949-1957, 2011.

PEREIRA, F. S. et al. Physical quality of an oxisol cultivated with maize submited to cover crops in the precropping period. Revista Brasileira de Ciência do Solo. 34(1):211-218, 2010.

PRAGANA, R. B. et al. Qualidade física de latossolos amarelos sob plantio direto na região do cerrado piauiense. Revista Brasileira de Ciência do Solo. 36(1):1591-1600, 2012.

SIGMAPLOT. Sigmaplot for Windows, version 12. Systat software, Califórnia, USA, 2011. 
SILVA, F. F. et al. Propriedades físicas de um Latossolo Vermelho cultivado no sistema plantio direto.

Irriga.13(2):191-204, 2008.

SILVA, B. M. et al. Índice S no diagnóstico da qualidade estrutural de um Latossolo muito argiloso sob manejo intensivo. Bioscience Journal. 28(3):338345, 2012.

STRECK, C. A. et al. Relações do parâmetro S para algumas propriedades físicas de solos do sul do Brasil. Revista Brasileira de Ciência do Solo. 32(NE):26032612, 2008.
TORMENA, C. A. et al. Quantification of the soil physical quality of a tropical Oxisol using the $\mathrm{S}$ index. Scientia Agricola. 65(1):56-60, 2008.

VAN GENUCHTEN, M. T. A closed-form equation for predicting the hydraulic conductivity of unsaturated soil. Soil Science Society of America Journal. 44(5):892898, 1980.

VAN GENUCHTEN, M. T. et al. RETC version 6.02, 2009.Disponível em: $<$ http://www.pc-progress. com/en/Default.aspx? retc-downloads $>$. Acesso em 6 jan. 2013. 